\title{
Apion carrorum Anderson and Alonso-Zarazaga, New Species, the First Representative of the Genus Apion Herbst (Coleoptera: Brentidae: Apioninae) in North America
}

\author{
Robert S. ANDERson \\ Beaty Centre for Species Discovery \\ Canadian Museum of Nature \\ PO Box 3443, Station D \\ Ottawa, ON K1P 6P4, CANADA \\ randerson@nature.ca \\ AND \\ Miguel A. Alonso-Zarazaga \\ Depto. de Biodiversidad y Biología Evolutiva \\ Museo Nacional de Ciencias Naturales \\ C/. José Gutiérrez Abascal, 2, E-28006 \\ Madrid, SPAIN \\ zarazaga@mncn.csic.es
}

\begin{abstract}
Apion carrorum Anderson and Alonso-Zarazaga, new species, is described from Plateau Mountain $\left(50.20741^{\circ} \mathrm{N}\right.$, $\left.114.52101^{\circ} \mathrm{W}\right)$, Alberta, Canada along the edges of melting snowfields at about 2,400 m elevation. This represents the first description of a species of the genus Apion Herbst in North America. It appears that the species is most similar to Apion arcticum Korotyaev, known only from Wrangel Island in the Russian Far East. Candidate species of Rumex L. as the possible host plant for $A$. carrorum are discussed.
\end{abstract}

Key Words: weevil, taxonomy, Nearctic, Apion arcticum, Rumex

DOI.org/10.1649/0010-065X-73.4.889

Zoobank.org/urn:lsid:zoobank.org:pub:3B88F207-4193-4D5C-A6D0-81A162C4261

In 1981, John L. Carr of Calgary, Alberta showed one of us (RSA) specimens of a large, red Apion Herbst that he had collected around the edges of a melting alpine snowfield on Plateau Mountain, in the front range of the Rocky Mountains just west of Calgary. At the time a novice, RSA thought it no more than another of the many species of Apion (in the broad sense), but John assured him that as far as he knew, there were no large, red Apion in North America. Shortly thereafter, RSA forwarded specimens to Donald R. Whitehead in Washington, DC. He concluded that it was a species of the subgenus Apion (sensu stricto), and that as this group of Apion was known only from the Palearctic Region, the specimens represented a new record of that subgenus for North America. But was this the first record of a Palearctic Apion species introduced into North America, or was this an undescribed species? In subsequent years, specimens were sent to David G. Kissinger and MAA$\mathrm{Z}$, but as the genus Apion (now elevated from subgeneric rank) contained 15 very closely related and polymorphic Palearctic species (Alonso-Zarazaga 1990), they were similarly unsure of its nature and origins. That the specimens were found along the edges of an isolated, high elevation, alpine snowfield, with no evidence of any surrounding anthropogenic influence, suggested that the species was indeed native and likely undescribed.

In 2000, while preparing the Brentidae part (which included the Apioninae; Anderson and Kissinger 2002) for Volume 2 of American Beetles, RSA reencountered this issue and with MAA-Z decided to try to resolve the problem. It has taken longer than hoped, but herein we describe Apion carrorum Anderson and Alonso-Zarazaga, new species, in recognition of John L. Carr and his wife Bert, both now deceased, who first drew attention to this species and collected all specimens, save for two, in the type series. These additional two specimens, from Idaho Peak, British Columbia (49.9725 $5^{\circ} \mathrm{N}, 117.3018^{\circ} \mathrm{W}$ ) and Graham-Laurier Provincial Park, British Columbia $\left(56.5171^{\circ} \mathrm{N}, 123.6859^{\circ} \mathrm{W}\right)$ were found in the collections of the Royal British Columbia Museum.

The genus Apion is easily recognized among other apionines by its uniform red color, separated (although very narrowly) mesocoxae, relatively 
large size, short and separate apical portions of striae 9 and 10, and structure of the genitalia. As noted, there are 15 Palearctic species in the genus. The discovery of $A$. carrorum represents the first record of the genus Apion in North America. Where known, Palearctic species are all associated with plants of the family Polygonaceae, usually of the genus Rumex L. Larvae mine stems, collars, and roots.

\section{Material and Methods}

Specimens of $A$. carrorum were compared with most of the European species and with photographs of the holotype of Apion arcticum Korotyaev. We also used the key of Dieckmann (1977) in an attempt to verify that the North American species is different from any in Europe. We used geography combined with the low likelihood of introduction as additional factors in considering this species as undescribed. We follow the generic description of AlonsoZarazaga (1990) in selecting characters for use in the species description.

Specimens are deposited in the collections of the Canadian Museum of Nature, Ottawa, Canada (CMNC); the Canadian National Collection of Insects, Ottawa, Canada (CNCI); the Royal British Columbia Museum, Victoria, Canada (RBCM); and the collection of Miguel A. Alonso-Zarazaga in the Museo Nacional de Ciencias Naturales, Madrid, Spain (MNCN).

\section{Apion carrorum Anderson and Alonso- Zarazaga, new species}

Zoobank.org/urn:lsid:zoobank.org:act:FF7EF31D7D81-47B5-9575-7C57688AE993

(Figs. 1-8)

Type Material. Holotype male labeled "Tp. 15 Rge 4 / W. 5 Mer. Alberta / 21.vii.1979 / Lot 1 BF\&JL Carr" (CNCI). Paratypes: 1 male, 6 females. Same locality but 6.vii.1980 (1 female; CNCI); 22.vi.1980 (3 females; CMNC); 6.vii.1980 (1 male, 1 female, MNCN); 6.vii.1982 (1 female, CMNC). British Columbia, New Denver, Idaho Peak, 49.9725, -117.3018, 2280m, 1.viii.2011, R. Bennett, C. \& D. Copley (1 female, RBCM [ENTO11-009772]). British Columbia, Graham-Laurier Provincial Park, Poutang Creek, 1896m, 56.5171, -123.6859, 31.vii.2018, C. \& D. Copley, R. Bennett, K. White (1 female, RBCM [ENTO18-014533]).

Description. Body length (exclusive of head and rostrum) $2.68 \mathrm{~mm}$ (male), 2.80-3.10 $\mathrm{mm}$ (female). Color reddish testaceous throughout (Fig. 1-2), legs and apex of rostrum slightly lighter, claws black. Vestiture of very fine, narrow, appressed, golden setae throughout, setae arranged in 2-3 irregular rows on elytral interstriae, centripetal on pronotum. Head with punctate postocular genal region (to anterior margin of pronotum) about as long as diameter of eye in male, slightly longer in female, shorter than distance between eyes across frons. Rostrum very slightly sexually dimorphic, that of male slightly shorter, more distinctly punctate and pubescent than of female, distinctly ventrally arcuate in both sexes. Point of antennal insertion at about basal $1 / 3$ rostral length in both sexes $(0.37$ in male, $0.33-0.41$ in female). In dorsal view, rostrum very slightly expanded laterally at point of antennal insertion in both sexes. Subocular keels low, reaching middle of eye. Eyes convex, round. Frons flat, width $1.11 \mathrm{X}$ width of rostral apex in male, 1.25-1.37X width of rostral apex in female. Pronotum uniformly finely, densely punctate, with very narrow median sulcus from midlength extended and widened posteriorly to elongate prescutellar fovea; in dorsal view, slightly widest at about midlength, narrowed apically, less so basally, slightly wider than long (width/length ratio $=1.19$ in male, $=$ 1.11-1.24 in female). Elytra widest at about midlength, longer than wide (width/length ratio $=0.71$ in male, $=0.57-0.67$ in female), $2^{\text {nd }}$ stria at base curved to scutellum. Abdominal ventrites 1 and 2 strongly convex, ventrites 3-5 flat and in a different plane from 1 and 2, ventrite 4 slightly longer than 3 , ventrite 5 slightly longer than 3 and 4 combined (Fig. 3). Mesocoxae distinctly separated in male, less so in female. Penis very uniformly cylindrical, slightly ventrally arcuate, more so apically, tip very slightly recurved, laterodorsal margins of apical

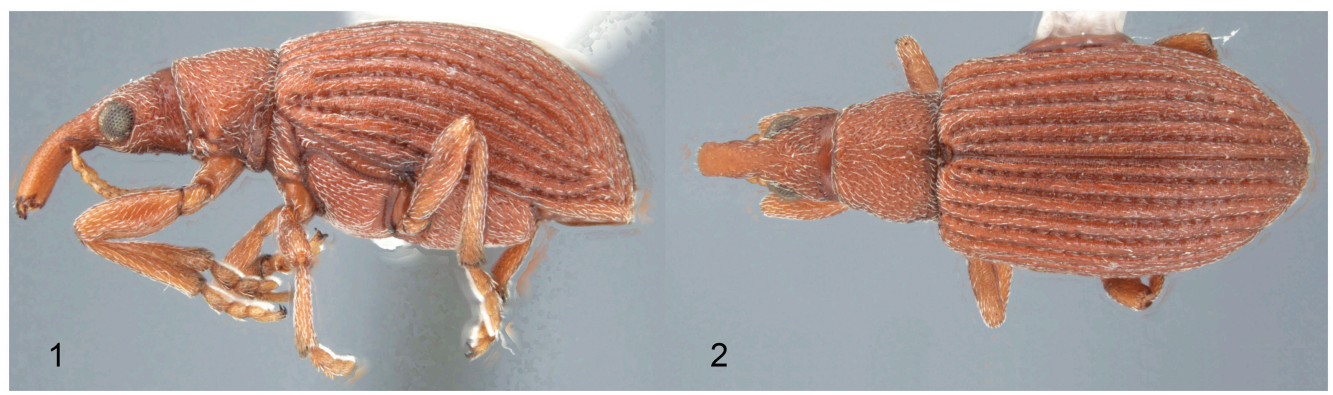

Figs. 1-2. Apion carrorum, female, lateral and dorsal habitus, respectively. 


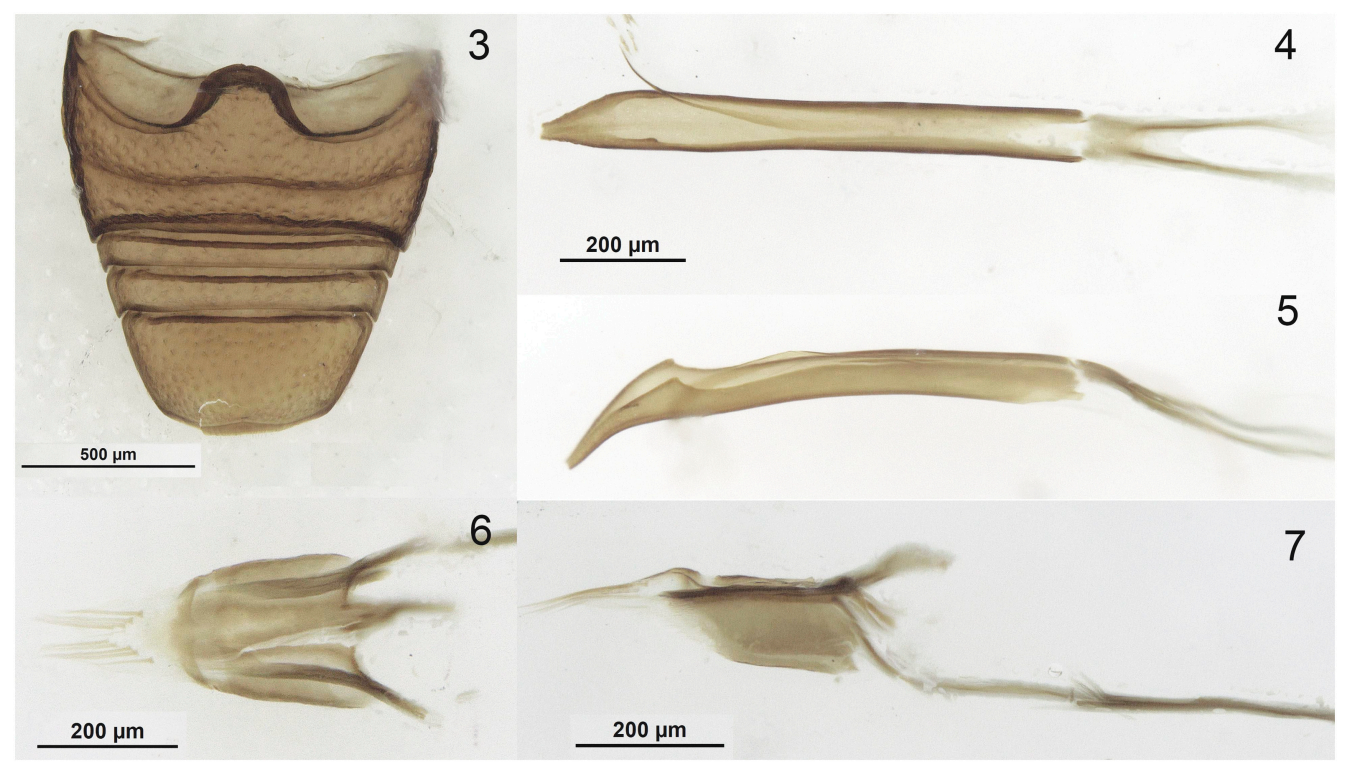

Figs. 3-7. Apion carrorum, male. 3) Abdomen, ventral view; 4-5) Penis, dorsal and lateral views, respectively; 6) Tegmen, dorsal view; 7) Prostegium, lateral view.

plate protruded, tooth-like; in dorsal view, with apex tapered, narrowly truncate at tip (Figs. 4-5). Tegmen with parameroid lobes medially produced, not separated, with a number of large transparent setae (Fig. 6). Prostegium with high median crista projected basally as flexed digitiform fin (Fig. 7).

Distribution. The species is known only from three localities (Fig. 8): Plateau Mountain, Alberta $\left(50.20741^{\circ} \mathrm{N}, 114.52101^{\circ} \mathrm{W}\right)$; Idaho Peak, British Columbia $\left(49.9725^{\circ} \mathrm{N}, 117.3018^{\circ} \mathrm{W}\right)$; and the more geographically distant Graham-Laurier Provincial Park, British Columbia $\left(56.5171^{\circ} \mathrm{N}\right.$, $\left.123.6859^{\circ} \mathrm{W}\right)$. Carr's locality labels often used the Alberta Township System to designate the locality, a land surveying system used in the Canadian province of Alberta and other parts of western Canada; Tp. 15 Rge 4 / W. 5 Mer. corresponds to Plateau Mountain at the coordinates given above.

Natural History. Adults were collected along the sides of rocks around the edges of a melting snowfield in June and July in alpine tundra at an elevation of about 2,400 m on Plateau Mountain. No specimens were associated with any particular plant species. Specimens were collected in 1979, 1980, and 1982. No subsequent attempts at collection have been made. The Idaho Peak specimen was collected in August at 2,280 m elevation, and the GrahamLaurier Provincial Park specimen was taken in late July at $1,896 \mathrm{~m}$, both in similar alpine/subalpine habitat.

Other species in the genus Apion in Europe and Asia are associated with various Polygonaceae, specifically species in the the genera Polygonum L., Rumex, Calligonum L., and Atraphaxix L. (AlonsoZarazaga 1990). A number of species of Rumex are candidate hosts for $A$. carrorum. The native Rumex lapponicus (Hiitonen) Czernov occurs on Plateau Mountain (UBC Herbarium V119795) and the native Rumex occidentalis S. Watson and the nonnative Rumex acetosella (Linnaeus) Miller may also be present there. The related Oxyria digyna (Linnaeus) Hill is known from Idaho Peak (UBC Herbarium V204307).

Origin of Species Name. This species is named after John L. Carr (deceased 4 September 2006) and

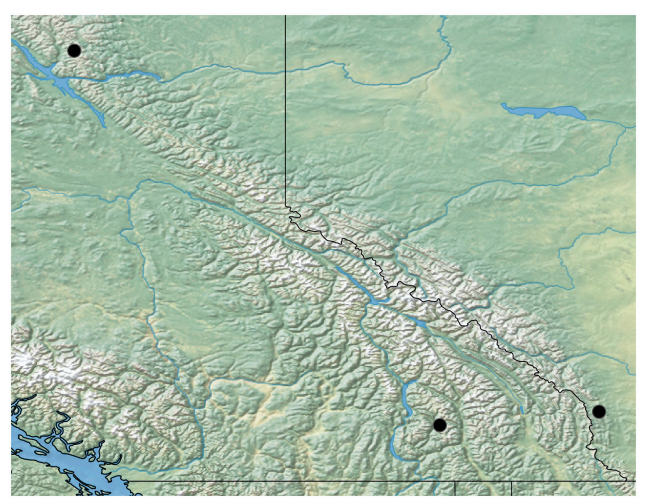

Fig. 8. Distribution of Apion carrorum in British Columbia and Alberta, Canada. 
Bertha F. Carr (deceased 3 February 2008) of Calgary, Alberta, Canada. John and Bert were terrific friends and field companions to the many Coleopterists (young and old) who had the pleasure of passing through southern Alberta. Many were those who enjoyed their hospitality and the excitement of a good day out 'beetling' in their company. Over the years since its collection, John and Bert would occasionally ask if the identity of "the big red Apion" had been resolved. I am sure they would have been very happy knowing that the problem had finally been addressed, that it was a new species, and that it had been named in their honor. John and Bert were winners of the 1990 Norman Criddle Award from the Entomological Society of Canada, given to recognize the contribution of an outstanding non-professional entomologist to the furtherance of entomology in Canada. The Carr collection of beetles is now in the Canadian National Collection of Insects in Ottawa.

\section{Discussion}

Apion carrorum belongs to the group of red Apion species having the long postocular genal region completely punctate, whose spatially closest relatives are the Palaearctic species Apion arcticum Korotyaev, 1988 and Apion cruentatum Walton, 1844. Apion arcticum is different in having a short and wide penis that is apically truncate (Korotyaev 1988, fig. 3). This is somewhat similar to the penis of Apion frumentarium (Linnaeus, 1758) but without the wide apical fan. On the other hand, $A$. carrorum has a rather narrow, elongate tube with the apex pointed, as is typical of most species of Apion, including $A$. cruentatum (Alonso-Zarazaga 1990, fig. 428). Apion carrorum and $A$. arcticum share the steep elytral declivity, the transverse pronotum, and the second elytral stria basally directed to the scutellum, but the general color of $A$. arcticum is darker than that of $A$. carrorum.

Apion cruentatum differs from $A$. carrorum in having less convex elytra, with a more oblique declivity, a subquadrate pronotum ( $c a .1 .05 \mathrm{X}$ as wide as long), the punctate postgenal region as long as the distance between the eyes, markedly less robust antennae, and the second elytral stria straight against the elytral base. They share the same color and cylindrical, elongate, apically tapered penis that has two lateral teeth on the apical plate.

As shown by Winter et al. (2017) in their phylogenetic tree (fig. 1), the Apion species having a long, punctate postgenal region do not form a monophyletic group, so that the presence of this character in A. carrorum is probably not a common trait with either $A$. cruentatum or $A$. arcticum. The rare character of the second elytral stria incurved basally towards the scutellum, together with the other characters mentioned above, seems to point towards a closer relationship with $A$. arcticum, known for the moment only from Wrangel Island in the Chukotka province of the Russian Far East.

\section{ACKnowledgments}

We thank Bruce Bennett, Yukon Conservation Data Centre, YT and Frank Lomer, Beaty Biodiversity Museum, BC for suggesting the candidate host Rumex species. Joel Gibson and Claudia Copley facilitated a visit to the collections of the Royal British Columbia Museum, and Claudia Copley recognized and provided an additional paratype from recent fieldwork in 2018.

\section{References Cited}

Alonso-Zarazaga, M. A. 1990. Revision of the supraspecific taxa in the Palaearctic Apionidae Schoenherr, 1823 (Coleoptera, Curculionoidea). 2. Subfamily Apioninae Schoenherr, 1823: Introduction, keys and descriptions. Graellsia 46: 19-156.

Anderson, R. S., and D. G. Kissinger. 2002. Chapter 129. Brentidae [pp. 711-719]. In: American Beetles Polyphaga: Scarabaeioidea through Curculionoidea, Volume 2 (R. H. Arnett, Jr., M. C. Thomas, P. E. Skelley, and J. H. Frank, editors). CRC Press, Boca Raton, FL.

Dieckmann, L. 1977. Beiträge zur Insektenfauna der DDR: Coleoptera - Curculionidae (Apioninae). Beiträge zur Entomologie, 27(1): 7-143.

Korotyaev, B. A. 1988. Novye dolgonosiki (Coleoptera, Apionidae, Curculionidae) Fauny SSSR. Trudy Zoologicheskogo Instituta AN SSR, 164 [1987]: 142-147.

Winter, S., A. L. L. Friedman, J. J. Astrin, B. Gottsberger, and H. Letsch. 2017. Timing and host plant associations in the evolution of the weevil tribe Apionini (Apioninae, Brentidae, Curculionoidea, Coleoptera) indicate an ancient co-diversification pattern of beetles and flowering plants. Molecular Phylogenetics and Evolution, 107: 179-190.

(Received 19 March 2019; accepted 18 August 2019. Publication date 19 December 2019.) 